Marquette University

e-Publications@Marquette

Economics Faculty Research and Publications

Economics, Department of

$1-1-1997$

\title{
Harcourt as a Historian of Economic Thought
}

John B. Davis

Marquette University, john.davis@marquette.edu

Published version."Harcourt as a Historian of Economic Thought", in Capital Controversy, Post Keynesian Economics and the History of Economic Thought: Essays in Honour of Geoff Harcourt, Vol. 1. Eds. Philip Arestis, Gabriel Palma and Malcolm Sawyer. London: Routledge, 1997: 401-410. Publisher Link. (C) 1997 Routledge. Used with permission. 


\title{
HARCOURT AS A HISTORIAN OF ECONOMIC THOUGHT
}

\author{
John B. Davis
}

In his first year at Cambridge to study for a Ph.D. in economics, Geoff Harcourt locked himself away for the better part of a term from friends, family and the temptations of Cambridge to read and study Joan Robinson's newly published The Accumulation of Capital (1956). He later testified that

The Accumulation of Capital had a profound effect on me. It presented a 'vision' of how capitalism works over time and, more tentatively, a conceptual framework with which to think about the processes involved and which made sense of what I saw happening around me. It formed the core from which my own work and teaching was from then on always to start.

(Harcourt 1992: 3)

He went on to add that one of the great virtues of Robinson's work was that she was able to synthesize the work of Smith, Ricardo, Marx, Marshall, Keynes, Kalecki, Kahn and, in her later work, Sraffa. The history of economic thought, seen through this Robinsonian lens, would form the backdrop for Harcourt's own thinking and many contributions to post-Keynesian theories of investment, pricing, employment and the distribution of income. It was also from this Robinsonian perspective that Harcourt wrote and continues to write the history of post-Keynesian economic thought, covering the Cambridge capital controversy, the post-Keynesian revival of classical political economy, contemporary post-Keynesian theory, and finally the history of 'Joan Robinson and her circle'.

It seems fair to say that no one has approached Harcourt's facility and insight in explaining how the different strands of post-Keynesianism weave together to produce a distinct and identifiable modern form of economic analysis and thinking. His advantage in this has in part been due to his having been at Cambridge at the time of the initial emergence of post-Keynesianism in the 1950s when it first began to become clear that Keynes's own thinking - as opposed to hybrid Keynesianism of the Samuelsonian sort - would not, and perhaps could not, be widely accepted by an economics profession 
fundamentally conservative in nature, Led by Robinson, Kahn, Kaldor and Sraffa, Cambridge then began to train a new generation of economists who were conscious of the fact that they were producing theory following new pathways, though with origins more than a century old in classical political economy. Harcourt was a member of this new generation; a member, as he puts it, of the class of 1955-8. But Harcourt's advantage in explaining postKeynesianism and its history is also due to his talent as a historian of ideas, which has enabled him to survey the structure and significance of contemporary economic ideas, especially in their relation to the issues facing modern economies. It was this that enabled him to make his initial foray into the history of thought in his definitive and unequalled history of the Cambridge capital controversy. Writing the history of the debate practically as fast as it happened, Harcourt demonstrated a gift in grasping the present as history.

This chapter outlines Harcourt's contributions to the history of postKeynesian economics both to draw attention to the scope of his achievements as a historian of ideas, and to help explain the nature of post-Keynesianism itself. It is important to understand the latter objective to appreciate the former. Post-Keynesianism's different currents sometimes create the impression that the term 'post-Keynesian' lacks an identifiable referent. Post-Keynesian economics may none the less be identified as the product of a succession or accumulation of theoretical innovations in economics aimed at helping us understand modern industrial, monetary economies. Harcourt has focused upon the quarter-century history of the emergence of post-Keynesianism at Cambridge influenced most by Keynes, Sraffa and Kalecki. That history was first told in terms of the Cambridge capital controversy (see below), was next deepened through discussion of the post-Keynesian revival of classical political economy traditions (the subject of a section starting on p. 448), was then broadened by a gathcring of related movements in the identification of post-Keynesianism as an approach and method (see p. 450), and is currently being re-examined from the perspcctive of the original contributions of 'Joan Robinson and her circle' (p. 452).

\section{THE HISTORY OF THE CAMBRIDGE CAPITAL CONTROVERSY}

The Cambridge capital controversies had their origin in Robinson's critique of the aggregate production function (1953-4), drew inspiration from Sraffa's classic work (1960), and climaxed in the reswitching and capital-reversing debates of 1965-7. The controversies surely represent one of the more paradoxical episodes in the history of economic thought. Two different groups of some of the world's best-known and talented economists representing two different long-standing traditions in the history of economic thought engaged in a protracted, intense intellectual exchange for nearly ten years over one of 
the most important issues in economic theory and in capitalism, but none the less largely misunderstood one another, often failing to communicate at all, with the result that though the debates arguably produced a reasonably clear set of conclusions, few economists today either recognize their importance or grasp their implications for current economic theory. Indeed, many of the participants in the debates confined themselves to citing the errors of their opponents. Harcourt, however, drew valuable conclusions about the significance of the debates for post-Keynesian economic thinking and economics generally.

The lack of communication and misunderstanding between the two Cambridges was in good part due to the fact that the Cambridge, England, critique of marginal productivity theory specifically targeted the aggregate production function. One response from Cambridge, Massachusetts, was that this did not preclude consideration of the marginal products of individual capital goods, and thus that no serious critique of marginal productivity theory was involved. Throughout the later debates over reswitching and capital reversing, this point remained unresolved, with Cambridge, Massachusetts, insisting more and more as the flaws of aggregate production function thinking became apparent that marginal productivity theory had its principal home in general equilibrium analysis, and Cambridge, England, insisting that aggregate analysis was central to any understanding of the economy as a whole.

What explained this breakdown in communication between the two sides? Harcourt drew on Robinson, who had argued that the problem was not about the measurement of capital but rather about its meaning, where this involved specifying the nature of a capitalist economy in terms of its institutions and rules, one of which would presumably be that in a system in which one class owned the mcans of production, a uniform rate of profits had to be paid on all capital goods. Harcourt thus commented in his 1976 'Cambridge controversies' review of the debates:

What is involved is the relevant 'vision' of the cconomic system and the historical processes associated with its development. In particular, stress is laid by the Cambridge (England) school on production and distribution as involving underlying social relations, especially their implication for production and distribution, accumulation and growth.

(Harcourt 1992: 133)

Cambridge, Massachusetts, however, insisted, in the words of Frank Hahn, that what all one needed to do, or could do, was 'to get the purely technical argument right' (Hahn 1972: 2; quoted in Harcourt 1992: 132). Importantly, this presupposed that in the social sciences ideology and analysis could be easily and clearly separated, a proposition that Cambridge, England, following the lead of Dobb 1973: 4-7), firmly rejected. This methodological disagrcement, Harcourt recognized, had concrete implications for the prog- 
ress of the debates. Because Cambridge, Massachusetts, believed that ideology and analysis could and ought to be kept separate, it came to conclude that the unwillingness of Cambridge, England, to keep them separate demonstrated an ideological rather than scientific motivation. This ultimately also justified the attitude that ultimately many assumed in the Cambridge, Massachusetts, tradition toward the debates, namely, that they had never involved a truly scientific exchange, and ought accordingly to be ignored along with, for that matter, all the thinking associated with Cambridge, England.

The effect on Cambridge, England, and the future of post-Keynesian thinking was decisive. Whereas once in the respectably scientific and highly influential tradition of Keynes, the thinking of Cambridge, England, abruptly became outcast in the mid-1970s, its ideas increasingly proscribed from the economics curricula of major universities, first in the United States and then gradually elsewhere, on the supposed but largely unexamined grounds that it was methodologically corrupt and unscientific. ${ }^{1}$ This could not but have surprised Cambridge, England, economists, who had not only correctly identified important flaws in marginal productivity thinking as an account of the modern industrial economy only to have them disregarded, but who had had good reasons worth discussion rather than simple dismissal for maintaining the connectedness of ideology and analysis. Post-Keynesianism, then, first emerged as a distinct form of economics as a result of these developments, in that its body of theoretical and methodological assumptions acquired an inadvertent unity and relative autonomy by virtue of their outcast status. Subsequent development of post-Keynesian thinking, then, not only built upon the theoretical foundations established by Cambridge, England, in the debates, but did so with an awareness of the importance of the methodological positions involved. One of Harcourt's most important judgements regarding the Cambridge controversies emphasized this latter point.

Although lack of communication and misunderstanding characterized much of the debates between the two Cambridges, their most ironic aspect, Harcourt concluded, was that their "climax itself was not very satisfying, because it occurred in the wrong - or at least not in the most important or fundamental - areas' (1992: 130). Were one to suppose that the Arrow and Hahn general equilibrium theory was the only viable form of marginal productivity theory,

the sorts of questions that the classical political economists were attempting to answer, in particular, the determination of relative shares of profits and wages as capital goods accumulate over time, and what happens to the living standards of broad class groupings, to the rate of profits (the uniform, long-run, natural or normal rate of profits, that is) and to the techniques of production in the process - broad, aggregative, 
sociological questions associated with the 'laws of motion' of capitalist societies - would end up unaddressed

(ibid.: 135)

One reason for this, Harcourt explained, is that general equilibrium theory is 'not explanatory ... nor a descriptive hypothesis, principally because it cannot handle historical time' (ibid.: 136). Throughout the capital controversies Robinson had always insisted that at root in Cambridge, Massachusetts, thinking was 'an error in methodology - a confusion between comparisons of imagined equilibrium positions and a process of accumulation going on through history' (Robinson 1974: 11), Real-world economies did not operate in logical time, however, but through causal processes in historical time.

The Keynesian method is to describe a set of relationships (intended to correspond ... to the relevant features of the economic system) and to trace the effects in the immediate and further future of a change taking place as an event at the moment of time.

(Robinson 1975: 92)

That there was no communication on this issue, Harcourt saw, meant that there could be no resolution of the many different points in contention between the two Cambridges. The particular effect this had on the future development of post-Keynesianism, howevcr, was for Cambridge, England, economists to grasp clearly that economic methodology required attention to real, causal, historical processes, which created a basis for investigation of those "broad, aggregative, sociological questions associated with the "laws of motion", of capitalist societies' investigated in classical political economy. This meant that early post-Keynesians next set out to re-explore and revive the assumptions of that mode of thinking.

\section{THE REVIVAL OF CLASSICAL POLITICAL ECONOMY}

Harcourt's most important contribution in this regard was his 1975 Economic Record review essay of four books (Harcourt 1975a), Dobb's Theories of Value and Distribution (1973), Hahn's The Share of Wages in the National Income (1972), Hicks's Capital and Time (1973) and Johnson's The Theory of Income Distribution (1973). Dobb (1975), Hahn (1975) and Hicks (1975) later responded to the review, and Harcourt (1975b) replied to their comments. $^{2}$ His initial premise was that each of the four was essentially "concerned with the great problems of the classical political economists distribution and the theory of value, allied with the process of accumulation of capital goods over time in a decentralized economy, usually competitive, capitalist economy' (Harcourt 1992: 101). What distinguished the four authors, however, was the prominence or neglect each accorded distribution 


\section{HARCOURT AS A HISTORIAN OF THOUGHT}

and production, and specifically, whether one held to "the dependence of the price structure on distribution', or favoured 'the converse dependence of distribution on a demand-determined price-structure' (Dobb 1973: 266; quoted in Harcourt 1992: 112). Here Harcourt found invaluable Dobb's understanding of the history of economic thought in terms of two competing traditions, which differently conceived the relationship between analysis and ideology, and which disagreed on the scope of political economy. These issues linked to the question of whether one reasoned in terms of universal general laws, or adopted a historical-relativist position which emphasized institutions and time.

For Harcourt, Hahn represented an interesting case on account of his employing a simultaneous-equations methodology to add an account of the distribution of income to Keynesian analysis of overall economic activity. In response to Harcourt's charge that this ran counter to Keynes's and Kalecki's emphasis upon the idea of a one-way process of direction from investment to savings, Hahn reasserted the themes of mathematical mutual dependence, suggesting in the process that post-Keynesian economists were guilty of the most incomprehensible mistakes in reasoning. A better example of Dobb's thesis of two competing (and non-communicating) traditions in economic thinking might not be found. As Harcourt noted in his reply, the real problem here seemed to be that post-Keynesians were concerned with classical questions - accumulation over time, the distribution of income between classes, the role of a uniform natural rate of profits in a capitalist economy which were matters that modern general equilibrium theory was never intended to address. 'Hahn has ignored the criticism that the wrong approach may have been used to model the world for particular questions' (Harcourt 1992: 126), and this meant that misunderstanding and lack of communication were likely to prevail.

Hicks, interestingly, took the occasion of his comment to emphasize the historical methodology intentionally applied in his later work generally, a feature which he believed Harcourt had not appreciated in reviewing Capital and Time, and which he allowed was missing from his earlier, better-known work. Given this, he then argued that economies out of equilibrium may none the less be understood to converge to equilibrium when certain simplifying assumptions are adopted. One of Harcourt's original concerns was which such simplifying assumptions might justifiably be made, specifically regarding whether wages are fixed or variable, when one was trying to understand the role of the surplus in modern economies. But Hicks's view of history required an equilibrium concept. It was an excellent example of a framing concept that Dobb would term ideological.

Interestingly, after Dobb's book had appeared, Hutchinson (1974) had argued that Dobb was wrongheaded in attempting to justify a role for 'individual motivation' in economic analysis. Dobb thus replied in his comment that his emphasis on ideology rather concerned 'the extent to which 
the shaping of any model, or set of abstract propositions in a subject ... is inevitably influenced ... by what may be termed a larger conceptual framework of ideas about the nature of existing society and its history' (quoted in Harcourt 1992: 118). This restatement of Dobb's view was seconded by Harcourt in his own reply. It reflected his recent experience over the reception to his comments on ideology in his book on the capital controversies (Harcourt, 1972), where it was clear that there was very little sympathy for considering any possible role the concept of ideology might have in theoretical disputes. It may also have been behind Johnson's unwillingness even to reply to Harcourt's original review on the grounds that Johnson thought that Harcourt simply did not like his book - an interpretation of ideological differences reduced to personal motivation.

Thus again, not only did deep-seated differences divide economists from different traditions, but individuals from these traditions were also unable to communicate about fundamental methodological issues. The great virtue of the exchange that came out of Harcourt's Economic Record review essay, however, was to make clear that there were these very different traditions, that post-Keynesianism with its interest in the 'broad, aggregative sociological questions' facing economies had natural roots in classical political cconomy, and that there was unlikely to be much overlap of interest between postKeynesianism and the economics of Hahn, Hicks and Johnson. What needed to be done, then, was to map out the distinctive contours of this tradition with its classical political economy antecedents in its contemporary development in connection with modern industrial economies.

\section{THE BROADENING OF POST-KEYNESIANISM AS A DISTINCTIVE TRADITION}

In an often-cited paper, (Hamouda and Harcourt 1988), Harcourt turned to the task of explaining the nature of post-Keynesianism per se (see also Harcourt 1982). Despite the many papers already on the subject, the controversial character of the issues, the diversity of theories and the ideological suspicions of many in the economics profession still left it unclear to many just what post-Keynesianism involved. Harcourt, however, chose to explain postKeynesianism as a single approach according to the different routes by which it had come out of classical political economy. He discerned three strands of thinking distinguishing major groups of thinkers, and also identified a collection of outstanding individual figures who defied classification within any one strand. Emphasizing the continuity with classical political economy made the surplus approach central to theories of value and distribution. The classicals had also sought an analysis of gravitational natural prices rather than supply-and-demand market prices, and treated money as a veil via the quantity theory over a real economy governed by Say's law. Clearly, these 
basic ideas allowed for different elaborations in the context of modern industrial economies.

One strand led to Marshall. Marshall preserved the classical dichotomy between value and distribution, on the one hand, and money, on the other (though abandoning surplus thinking by explaining long-period normal prices in terms of supply and demand). Keynes pursued the money side of this classical vision and, though retaining the classical emphasis on broad, sociological relationships, ended up throwing over the quantity theory, Say's law and the classical dichotomy for an analysis of a monetary production economy. North American post-Keynesianism (Weintraub, Tarshis, Davidson, Minsky) took up this conception, and added an account of the aggregate supply function. The latter took firm price or sales proceeds expectations (according to the form of competition assumed) as a starting point, and investigated how entrepreneurs would react if these short-period expectations went unfulfilled. Analysis of the economy as a monetary production economy emphasized uncertainty, the centrality of the money wage, the properties of money liquidity, and financial instability.

A second strand of post-Keynesianism, a neo-Ricardian one, derives from Sraffa's rehabilitation of the surplus approach, emphasizes the importance of a long-period approach to income and employment, and firmly rejects any elements of a subjective theory of value. Sraffa's work laid the basis for the critique of aggregate production function analysis central to the Cambridge capital controversies. It also led to important disagreements with those postKeynesians attached to Keynes's downward-sloping marginal efficiency of capital and investment schedules, which were regarded as inconsistent with the main results of the capital theory debates. This conflict suggested to some that neo-Ricardian economics was fundamentally different in nature from other strands of post-Keynesianism. Putting aside questions of semantics, Harcourt's strategy was to show that in terms of Dobb's two competing traditions, neo-Ricardianism and monetary production post-Keynesianism none the less shared the same classical heritage.

The third strand Harcourt distinguishes passes through Marxian economics, stressing the significance of social relationships in the sphere of production, the technical structure of production, and the potential surplus available at any moment of time. The real wage is determined in class conflict, and whether the potential surplus is realized depends upon the interplay between an accumulation function (in the sense of Robinson's 'animal spirits' function) and a savings function reflecting the distribution of income. Kalecki was especially influential here in combining Keynes's effective-demand analysis and Marx's reproduction schemes. Robinson represented the twosided relationship between accumulation and profitability with her famous banana diagram. The micro-foundations of the approach were developed from Kalecki's degree of monopoly mark-up view by a variety of individuals. Contributors have none the less differed over the relative importance of long- 
run and short-run factors in explaining price-setting.

Finally, Harcourt takes Kaldor, Goodwin, Pasinetti, Shackle and Godley to be beyond classification. Yet all share classical presuppositions in their work, and are consequently labelled post-Keynesian. Harcourt's survey of postKeynesianism, then, demonstrates the existence of a shared orientation across very different types of thinkers based on their common concern with 'concrete situations, the historical experience and the sociological characteristics of the economies' they study (Hamouda and Harcourt 1988: 231). All, it might be said, sought to fit theories to the facts they found rather than fit facts to pre-held theories - a formalist trait characteristic for Dobb of the other great tradition in economics that emerged after classical political economy. Given this distinction, to attempt to place all types of post-Keynesian thinking in a single schema is a misplaced exercise. Different levels of abstraction and different issues necessarily produce different types of theories. This methodological conviction is specifically post-Keynesian.

\section{'JOAN ROBINSON AND HER CIRCLE'}

Harcourt's largest and most recent project in writing the history of postKeynesian economic thought involves explaining the thought of 'Joan Robinson and her circle', the first economists who were self-consciously postKeynesian. Robinson, Kahn, Kaldor and Sraffa were not only the first to see that Keynes's and Kalecki's work departed in fundamental ways from Marshallian thinking, but also to see that it did so by reintroducing classical questions and concerns into modern economics. They were also the first to see that new divisions within the economics profession - initially brought about by Keynes's rejection of Say's law and the quantity theory of money, and then over the competing conceptions of the proper domain of economics produced in the Cambridge capital controversy - were likely to persist in the future.

Of course Harcourt's choice of Robinson as the central figure in this group naturally reflects his own commitments and interests in economics. Other post-Keynesians accord Sraffa greater importance (or Kalecki for that matter, though he was not really part of the post-Keynes 'circle' or in Cambridge for very long). Still, it is probably fair to say that the combination of Robinson's combative personal character and the hostile reception of post-Keynesianism by the majority of economists did make her a pivotal figure in the emergence of post-Keynesianism, and that any history of this emergence ought to ascribe to her a key role. Harcourt, however, puts his finger on something probably even more important: Robinson, especially in her Accumulation of Capital (1956), provided 'a "vision" of how capitalism works over time and, more tentatively, a conceptual framework with which to think about the processes involved' (Harcourt 1992: 3). In this respect, she very much was a follower of Keynes, who also emphasized the significance of economists' vision of the economy: 'Keynes himself (and others on his behalf, notably Joan Robinson) 


\section{HARCOURT AS A HISTORIAN OF THOUGHT}

claimed that he tried to change our method of doing economics as well as our way of seeing how our economies work' (Harcourt and Sardoni 1994: 132; emphasis in original). Thus it is Robinson's particular 'vision' of both the operation of the economy as a whole and the way of approaching its explanation that we need to attend to in order to understand Harcourt's history of the beginnings of post-Keynesianism.

That vision matured in The Accumulation of Capital, and combined Keynesian thinking about investment, animal spirits and finance with Marxian ideas regarding reproduction and realization via Kalecki to create an understanding of capitalism as a historical process (Harcourt and King 1995: 40-2). It was heavily influenced by Sraffa's work on Ricardo and the concept of the surplus, and affirmed the distinctiveness of classical political economy. Indeed, Harcourt suggests that one of Robinson's virtues was her ability to synthesize hers and others' ideas, and that she was less concerned about getting credit for things than getting things right. This meant that, at least for a time, Robinson's vision reflected the Cambridge, England, view (especially for those at Cambridge, Massachusetts), so that telling the history of 'Robinson and her circle' is simply telling the history of the circle. Much the same might be said about the earlier 'Cambridge circus' (despite Kahn's special role in communicating with Keynes).

Sadly, the passing of Robinson, Sraffa, Kaldor and Kaim by the mid-1980s has left Cambridge with few post-Keynesians, and, lacking a single, prominent university location and the notoriety of the original followers of Keynes, post-Keynesianism has struck some as less substantial as an alternative method and body of economics than it in fact is. Yet not only are the number of active post-Keynesians and the range of new developments based on the work of 'Robinson and her circle' quite extensive, but postKeynesians today are generally aware that they share a distinct tradition in the history of economics with specific methodological commitments to a historically informed analysis of modern economies. Harcourt's history of post-Keynesian origins counts as an important contribution to the development of this understanding.

\section{CONCLUDING NOTE}

Harcourt's claims for Joan Robinson cmphasize her vision and capacity as a synthesizer of ideas. In this respect he has always very much been her student both in having a vision of post-Keynesianism as a distinct and original tradition of thought, and in being able to explain the coherence of the range of post-Keynesian ideas. These talents, it turns out, are rarer than one might suppose, since few others seems to possess them. Indeed, in this respect postKeynesianism may find itself in a rather enviable position in that Dobb's other main tradition in economic thought seems to lack a figure comparable in talent and insight to Harcourt. 


\section{NOTES}

1 It is arguable that the decline of Keynesian macroeconomics in later years also had its origins in this development, since neoclassical-synthesis Keynesians were wedded to aggregate production analysis. New classical macroeconomics is based on a fully disaggregated, Walrasian analysis of the economy.

2 The original papers and later exchange are reprinted in Harcourt (1992: 101-29).

\section{RE F EREN CES}

Dobb, M. H. (1973) Theories of Value and Distribution since Adam Smith: Ideology and Economic Theory, Cambridge: Cambridge University Press.

(1975) 'Revival of political economy: an explanatory note', Economic Record 51(135): 357-9. Reprinted in Harcourt, G. C. (1992) On Political Economists and Modern Poltical Economy: Selected Essays of G. C. Harcourt, ed. C. Sardoni, London: Routledge.

Hahn, F. H. (1972) The Share of Wages in the National Income: An Enquiry into the Theory of Disrribution, London: Weidenfeld \& Nicolson.

- (1975) 'Revival of political economy: the wrong issues and the wrong argument', Economic Record 51(135): 360-4. Reprinted in Harcourt, G. C. (1992) On Poltitical Economists and Modern Political Economy: Selected Essays of $G$. C. Harcourt, ed. C. Sardoni, London: Routledge.

Hamouda, O. F. and Harcourt, G. C. (1988) 'Post-Keynesianism: from criticism to coherence?", Bulletin of Economic Research 40: 1-33. Reprinted in Harcourt, G. C. (1992) On Political Economists and Modem Political Economy; Selected Essays of G. C. Harcourt, ed. C. Sardoni, London: Routledge.

Harcourt, G. C (1972) Some Cambridge Controversies in the Theory of Capital, Cambridge: Cambridge University Press.

- (1975a) 'Decline and rise: the revival of (classical) political economy', Economic Record 51(135): 339-56. Reprinted in Harcourt, G. C. (1992) On Political Economists and Modem Political Economy: Selected Essays of G. $C$. Harcout, ed. C. Sardoni, London: Routledge.

- (1975b) 'Revival of political economy: a further comment', Economic Record 51(135): 368-71. Reprinted in Harcourt, G. C. (1992) On Political Economists and Modern Political Economy: Selected Essays of G. C. Harcourt, ed. C. Sardoni, London: Routledge.

- (1976) 'The Cambridge controversies: old ways and new horizons - or dead end?", Oxford Economic Papers 38(1): 25-65. Reprinted in Harcourt, G. C. (1992) On Political Economists and Modern Political Economy: Selected Essays of G. C. Harcourt, ed. C. Sardoni, London: Routledge.

- (1982) 'Post Keynesianism: Quite wrong and/or nothing new?', Thames Papers in Political Economy, London: Thames Polytechnic.

- (1992) On Political Economists and Modem Political Economy: Selected Essays of G. C. Harcourt, ed. C. Sardoni, London: Routledge.

Harcount, G. C. and King, J. (1995) 'Talking about Joan Robinson: Geoff Harcourt in conversation with John King", Review of Social Economy 53(1): 31-64.

Harcourt, G. C. and Sardoni, C. (1994) 'Keynes's vision: method, analysis and "tactics", in J. Davis (ed.) The State of Interpretation of Keynes, Boston and Dordrecht: KJuwer.

Hicks, J. (1973) Capiral and Time: A Neo-Austrian Theory, Oxford: Clarendon Press. (1975) 'Revival of political economy: the old and the new', Economic Record 51(135): 365-7. Reprinted in Harcourt, G. C. (1992) On Political Economists and 


\section{HARCOURT AS A HISTORIAN OF THOUGHT}

Modern Political Economy: Selected Essays of G. C. Harcourt, ed. C. Sardoni, London: Routledge.

Hutchinson, T. W. (1974) The Cambridge Version of the History of Economics, Occasional Paper 19, Birmingham: Faculty of Economics and Social Sciences, University of Birmingham.

Johnson, H. G. (1973) The Theory of Income Distribution, London: Gray-Mills.

Robinson, J. V. (1953-4) 'The production function and the theory of capital', Review of Economic Studies 21: 81-106. 1969.)

(1956) The Accumulation of Capital. (Second edition, London: Macmillan, (1974) 'History versus equilibrium', London: Thames Polytechnic.

(1975) 'Letter to the editor', Cambridge Review 97: 91-2.

Sraffa, P. (1960) Production of Commodities by Means of Commodities: A Prelude to a Critique of Economic Theory, Cambridge: Cambridge University Press. 